\title{
Euro-Med And Intercultural Management
}

\author{
Issam Atala, DBA \\ Sagesse University- Lebanon
}

doi: 10.19044/esj.2016.v12n4p201 URL:http://dx.doi.org/10.19044/esj.2016.v12n4p201

\begin{abstract}
As technological inventions and innovations are bewildering the human mind, destroying barriers between peoples, cultures, time and space, globalization trends are sweeping civilizations, nations, nationalisms and other ethnic narrow circles.

The winds of human revolutions overwhelm governments, leaders and citizens in pursuit of a better world, based on human freedoms and rights, economic well-being, peace and sustainable ecosystem. This positive cultural change is subjected to many obstacles and much dichotomy, whereby some do promote a negatively extreme pole of violence, terror and death.

The objective of this research is to deeply explore the inner venues of both trends, embraced by a new breed of international mangers, leaders, and further determine their impact upon the birth of a world culture, primarily adopted by international businesses.

The proposed methodology of research relies, primarily on data gathering from many thinkers and organizations aiming at laying a possible foundation for promoting intercultural management between Europe and the Middle Eastern countries.
\end{abstract}

Keywords: Civilizations, globalization, world culture, ecosystem, human freedoms

\section{Introduction}

The Arab region of the Mediterranean has been qualified as 'Arab spring', but, unlike what spring suggests, it is afflicted by storms of fear and violence. The Euro-Med partnership was hoped to promote freedom and equality instead of wars and terror.

Consequently, it is a must for researchers and readers to acquaint themselves with this region's cultures as well as the socio economic and political state of facts.

The region, politically, religiously is ruled by dictatorships since the seventh century. There is no separation between religion and all other aspects of human life. Religious leaders govern, legislate execute, judge and enjoy 
absolute power. The current revolutions and uprisings have been triggered by the people, in quest of advancing personal freedoms, cultural evolution and economic development.

The results so far, in spite of all efforts, associations, international agreements, spectacular physical achievements in wealth and construction, the human mind remains unchanged and imprisoned by a series of beliefs, taboos and laws, worse than before for it drifts in adoption of fundamental, intolerant behavior.

This research briefly identifies the Mediterranean countries with their huge differences in the areas of economy, culture, technology and even military power.

In contrast the European partners have long ago separated themselves from all forms of tyranny violence and intolerance. This paradigm of contradictions imposes upon scholars to examine the common cultural, economical, technological and social backgrounds the different Mediterranean countries, face as obstacles to change.

\section{Euro Med}

The Euro Med Parliamentary Assembly was established in Naples in 2003 by the Euro- Med ministers of Foreign Affair- EMPA. It was not a new institution inside the Euro- Med Partnership framework; rather it gathered parliamentarians from the Euro Mediterranean countries as it established four permanent committees to handle issues in the following areas:

1. Political Affairs, security and Human Rights.

2. Economic, financial, social affairs and education.

3. Promotion of the quality of life, human exchange and culture.

4. Women' Rights in the Euro- Med countries.

As a result, and following many criticisms for failure to attain most goals of the Euro Med Partnership, the UFM (Union for the Mediterranean) was established in July $13^{\text {th }}$ 2008. Since an autonomous Mediterranean Union plan was dropped. UFM is a multinational partnership that encompasses 43 counties from Europe and the Mediterranean basin. Its ultimate objective is to promote stability and prosperity throughout the Mediterranean region, and specifically the Middle Eastern countries. In order to attain these goals, a free Trade Area in the Euro-Mediterranean region was formed in 2010. UFM designed several concrete projects that faced the following obstacles during implementation:

1. Politics and security in often a volatile world, still living under medieval cultural practices and beliefs.

2. Economics and trade relating to issues of tariffs, technological transfer, international business, and so forth. 
3. Socio-cultural issues dealing with outdated beliefs, customs and traditions that have been major promoters of violence, conflicts and wars.

4. Weak judicial system and rule of law in managing internal affairs, whereby+ human rights are almost suppressed and corruption is at its height.

In 2008, the 43 Ministers of Foreign Affairs gathered in Marseilles, and identified 5 concrete projects targeting specific needs of the EuroMediterranean regions while enhancing the visibility of the partnership:

1. De-pollution of the Mediterranean: the target revolves around sustaining good environmental governance, wider accessibility to potable water, water management in general including the sea, pollution reduction of $\mathrm{CO}_{2}$ and protection of the Mediterranean biodiversity. According to the ENPI - European Neighborhood Instrument- €22 million were allocated for funding this project.

2. Maritime and land highways: the goal aims at improving the circulation of goods, commodities, and people throughout the EuroMed region by improving its ports, constructing highways and railways. ENPI allocated for this project $€ 7.5$ million.

3. Civil protection: the objective focused on progressively lead the Mediterranean Partner Countries closer to the European Civil Protection Mechanism" through socio-cultural development”.

4. Alternative Energies, like the Mediterranean solar plan to promote the production and use of renewable energies. €5million was allocated from the ENPI for this project.

It is evident that all these projects were promoted with meager financial allocations. A real budget would have been twenty times higher. Consequently the outcomes of these projects fell shorter than hoped for.

5. The Mediterranean business development initiative that aims at mainly assessing the needs of small and medium-sized enterprises from the Mediterranean partnership countries, and provide these SMEs with resources in the form of technical assistance and financial instruments.

The closing point in the chart focuses on the Anna Lindh Foundation for the Dialogue between Cultures. Due to sweeping globalization trends and the cross-cultural management concept, this new foundation was created along with the UN Alliance of Civilization at the Paris Summit (2008). This foundation will be in charge of the cultural dimension of the Union for the Mediterranean. The aim is to promote intercultural dialogue and mutual understanding. 
I.

Related to the cultural issues it is important to study the Euro Med Heritage Program launched in 1998 since it has been considered as the essential instrument for the preservation and evaluation of cultural heritage as well as a catalyst for mutual understanding between the populations of the Mediterranean region. This Euro Med Heritage Program -now in its $4^{\text {th }}$ developmental phase- has limited actions. Between 1998 and 2007, €57 million have been allocated for the financing of 52 projects involving entities and professionals working in the field of cultural heritage around the Mediterranean.” The recommendations resulting from the conference (done on 21-23 January 2013 in Fez, Morocco by the Euro Med Heritage) were designed to propose orientations for future strategic changes, among which an enhanced and better defined role of civil societies groups and the private sector would be defined, including their relationship with governmental authorities, as well as the framework definitions within which collaboration among them would occur. At the operational level, a stronger role was assigned to civil societies targeting higher return on investments through better planning and implementation of pilot projects, etc. These recommendations were designed to contribute to the formulation of a new strategy for cross-cultural management for 2013-2020. (The National Indicative program 2005-2006).

The strategies were divided into 2 parts corresponding to different specific tasks:

First the intent was to encourage cultural expressions promoting diversity, intercultural dialogue, human and cultural rights, all in the context of reconciliation, peaceful conflict resolution and democratization. Secondly, contribute to economic growth and sustainable development.

I) The Barcelona process and Euro Mediterranean Partnership.

The Barcelona Process is a unique and ambitious initiative that started in 1995 with the Barcelona Euro-Mediterranean Conference. It laid the foundations for a new regional partnership starting a turning point in Euro-Mediterranean relations. It consisted of 15 EU members (Austria, Belgium, Denmark, Germany, Spain, Finland, France, Greece, Ireland, Italy, Luxembourg, Netherlands, Portugal, United Kingdom, Sweden) and 14 Mediterranean partners (Croatia, Cyprus, Malta, Macedonia, Turkey, Algeria, Egypt, Israel, Jordan, Lebanon, Morocco, Syria, Tunisia, and Palestinian Authority). Its framework aimed at managing both bilateral and regional relations. The EU stated the intention of this partnership to strengthen its relations with the countries in the "Mashriq" and "Maghreb" regions. The role of the Barcelona process is to assure security and stability in the Mediterranean along with agreeing on shared values, and re-enforcing a long-term process for mutual cooperation 
in the Mediterranean, promoting democracy, good governance and human rights. (The Mediterranean, the World System and the Wider Europe. Vol. 1: The "Cultural Enlargement" of the EU and Europe's Identity)

II) Violence vs. Freedom.

Freedom of association, which is enshrined in article 20 of the Universal Declaration of Human Rights and in article 22 of the International Covenant on Civil and Political Rights, is inseparable from freedom of opinion, of expression and information. It plays a determining role in any democratic reform project. There can be no democracy without freedom of association, which acts, in many respects, as a barometer of the state of basic freedoms. The right to freedom of association includes the right to join, create and leave any group, association or society, regardless of its legal form and organization. It requires that the state refrains from interfering when an association is created, and carries out its activities (Chammari 2007). At the same time, it requires that the state contributes to developing and maintaining an environment favorable for the exercise of freedom of association. The right to join and establish associations is closely linked to the others civil and political rights, which are fundamental prerequisites for the promotion and protection of economic, social and cultural rights. Conversely, the full exercise of civil and political rights depends on the full realization of economic, social and cultural rights. (Ghantous, 2007).

The Universal Declaration of Human Rights; Article 20 (1) provides also that 'everyone has the right to freedom of peaceful assembly and association' while article 23 (4) states that 'everyone has the right to form and to join trade unions for the protection of his/her interests'. Article 8 (1)(a) of the International Covenant on Economic, Social and Cultural Rights provides that 'the States, Parties to the present Covenant, undertake to ensure the right of everyone to form trade unions and join the trade union of choice, subject only to the rules of the organization concerned, for the promotion and protection of economic and social interests. No restrictions may be placed on the exercise of this right other than those prescribed by law, and which are necessary in a democratic society, in the interests of national security or public order, or for the protection of the rights and freedoms of others'.

The Declaration on the Right and Responsibility of Individuals, Groups and Organs of Society to Promote and Protect Universally Recognized Human Rights and Fundamental Freedoms stresses the principles and criteria relating to the Freedom of Association in the Arab Countries, adopted at the end of a meeting by legal experts. The Amman Declaration was followed by the Casablanca Declaration 5 in October 2001. Despite repeated official speeches about safeguarding human rights and the rule of law, the situation in southern and eastern Mediterranean countries with respect to the effective safeguarding of basic human freedoms remains a 
source of grave concern. Since the September 2001 attacks on the US, most states in the region have been implementing 'repressive', strategies aimed at restricting freedom of association, of assembly and more of expression. Human rights violations and denials of justice are common practice along with multiple types of harassment, intimidation, abductions and violence against all demonstrators, protestors or dissidents. While some progress has been made, especially in Morocco and Lebanon, these gains are relative and in many respect uncertain. While the consequences and repercussions of Jihadi terrorism are undoubtedly significant, the systematic use of terror, more of less allowed by states creates a situation that raises grave concerns. The enjoyment of individual freedoms is extremely limited if not nonexistent in Tunisia and Libya. In Egypt and Syria, the domination exerted by the single-party state or the hegemonic and all-powerful government party gives rise to an all-pervasive state of arbitrariness faced by people who are subjected to the 'tyranny of obedience'. In Algeria, Egypt and Syria, a state of emergency is still in force (since 1992, 1981 and 1963, respectively). It is used to justify repressive measures and emergency laws.

While the threat of terrorism is real, policies that focus exclusively on security and practices curtailing freedoms failed to stop fundamentalism, extremism and fanaticism. The effects of laws purporting to fight terrorism and money laundering in countries such as Tunisia, the Gulf States and Jordan, for example, are likely to be the opposite of those anticipated.

\section{Restricting minority rights and culture}

Associations for the defense of minorities have been subjected to disproportionate limitations, including, on some occasions, harassment, by state securities. (Guillet, 2007).

The mayor of Florina has reportedly participated in those actions - of an association whose declared aims included the defense of the Macedonian minority living in Greece, the European Court of Human Rights found a violation of freedom of association stating that "mention of the consciousness of belonging to a minority and the preservation and development of a minority's culture cannot be said to constitute a threat to "democratic society", even though it may provoke tensions. The emergence of tensions is one of the unavoidable consequences of pluralism, where one freely discusses all political ideas. .(El Yazimi, 2012)

\section{Cultural Background}

The Euro-Mediterranean Partnership is almost 13 years old and it comprises a population of about 781 million. It includes different cultures, ethnicities, religions, political systems and historical civilizations. Mutual 
understanding and dialogue between members are essential bases for peaceful coexistence and joint development in the region. The Barcelona Declaration of 1995 recognizes the differences. Among its objectives, special attention was devoted to the social, cultural and human dimensions elements: "The participants recognize that the traditions of culture and civilization throughout the Mediterranean region are an essential factor in bringing the people closer, promoting understanding between them and improving their perception of each other" (Barcelona declaration 1995). Despite the many conflicts that have afflicted the region, the Mediterranean has long been the symbol of coexistence of cultures and traditions. People continue to promote exchanges, share knowledge and enjoy a common ground for survival. Today, the political and economic objectives of the Partnership remain highly challenged.

The Euro Med partnership has been during the recent years very active in promoting cultural cooperation, fostering dialogue between cultures and bringing people together. The willingness to listen to and understand one another, normally leads to a successful dialogue; since it relies on the art of communication between people.

The Barcelona Process sponsored several programs ranging from film screening, to youth exchanges, educational and technological transfers and the establishment of the Anna Lindh Foundation. Networks are built; partnerships are established and most importantly, people from both sides of the Mediterranean begin sharing common interests committing themselves to working together now and in the future. Regional intercultural dialogue has been at the heart of the Euro-Mediterranean partnership since the start. The activity concerned with networking, gave museums and other cultural institutions, students and university teachers, the opportunity to meet, connect and team up in their efforts to preserve the heritage treasures of their countries for present and future generations. The Euro Med Heritage II and III focused on tangible and non-tangible expressions of culture that identified the Mediterranean as unique, resulting in projects on cultural tourism, maritime and musical heritage, as well as regional traditions of food and craft. This trend of cooperation has developed into a strategy to discover Euro Mediterranean Cultural Heritage and Islamic art. (Benita FerreroWaldner Commissioner for External Relations and European Neighborhood Policy)

It gave birth to the virtual 'Museum with No Frontiers', allowing people from everywhere in the world to take note of the historical and cultural Arabic heritage around the Mediterranean. The project was initiated following a cycle of thematic exhibitions on Islamic Art in nine countries around the Mediterranean. Since, the museum gradually opened its doors to other collections. The program is based on combination between Egypt, 
Morocco, Jordan, Turkey, Tunisia, Algeria, Syria, Spain, Portugal, and Italy and is the collective work result of 250 experts from all over the region. Mobility programs such as Youth, Erasmus or Leonardo da Vinci have seen the enthusiastic participation of young children, academic and vocational students within the EU. The positive effects these programs had -and continue to have-on mutual understanding and intercultural learning have been apparent. Several participants learned a new language and their stay in another country led to long contacts and connections with people of that country. Furthermore, the important influence of media cannot be overlooked when considering intercultural dialogue. Satellite and terrestrial television, radio, newspapers and internet sites, all play a significant role in shaping the image and perception one has of other cultures. Words and images portrayed by different media were based on public opinion. Not surprisingly therefore, since the start of the Barcelona Process the media has formed relations between the EU and the Mediterranean partners. It must be noted that promoting Euro-Mediterranean ideas do not mean that there is a Euro-Mediterranean Identity.

The culture of Egypt has thousands of years of history; for Ancient Egypt was amongst the earliest civilizations. For millennia, Egypt maintained a complex and stable culture that influenced later the cultures of Europe, the Middle East and Africa. After the Pharaonic era, Egypt itself came under the influence of Hellenism, and thereafter Islamic culture. Today, many aspects of Egypt's ancient culture exist in interaction with newer elements, including the influence of modern Western culture.(Veni Vidi Travel).

As for Algeria, The territory of today's Algeria was the home of many ancient prehistoric cultures, including Aterian and Capsian cultures.

The culture of Turkey combines a heavily diverse and heterogeneous set of elements that have been derived from the Byzantine, Ottoman, European, Middle Eastern and Central Asian traditions.(Dr. Esra Ozkan and the ICE Team) The culture of Croatia has roots in a long history, for the Croatian people have inhabited the area for fourteen centuries; important fragment of the earlier periods are still preserved in the country. The Maltese islanders is the culture of Malta and reflects many societies that have come into contact with the Maltese Islands throughout the centuries, including neighboring Mediterranean cultures, and the cultures of the nations that ruled Malta for long periods of time prior to its independence in 1964. One would conclude that despite all the differences between the cultures of the EuroMed countries, there are common bonds that bring them together. People exchange practical experiences, learn and work together while following their passions, interests, ambitions, and simple curiosity. (Air France journal) 


\section{The Euro-Mediterranean Partnership Contribution}

The Euro-Mediterranean Partnership has provided a means to address several strategic regional questions relating to security, environmental protection, management of resources and economic relations through trade. Its Initiative, predominantly, comprises an economic agenda, and strategic plans to establish a free trade area encompassing 800 million people. It might be, for some analysts, a risky venture, since an accelerated economic liberalization in the southern Mediterranean could produce greater instability, conflicting with the central aim of the partnership. The effects of such liberalization would directly affect Algeria, Morocco and Tunisia. Despite the ambitious objectives behind the Barcelona process, the financial support offered to non-EU Mediterranean countries is small in comparison with the funds invested in convergence within the European Union. Furthermore, there is a question about whether the Southern States have the ability to address their own instability and reach the mandated level of socioeconomic and political reform.

Euro-Mediterranean Ministerial meetings have been regularly held to determine the political commitments that drive cooperation and activity across variable sectors. These periodic meetings examine the priorities and the progress made on different initiatives. With the introduction of the European Neighborhood Policy (ENP) in 2004, the Barcelona Process essentially became the multilateral forum of dialogue and cooperation between the EU and its Mediterranean partners, while complementary bilateral relations are mainly managed under the ENP, and through Association Agreements signed with each partner country. The EU works closely with each of its Mediterranean partners to formulate and develop strategies, through program support for economic transition and reform taking into account each country's specific needs and characteristics.

Political and security stability remain major priorities for the EuroMed partnership, especially as more violence globally creeps.

\section{Euro-Mediterranean Code of Conduct on Countering Terrorism}

The countries, members of the Euro-Mediterranean partnership, guided by the principles and objectives of the Barcelona Declaration, are united in the struggle against terrorism. The threat, terrorism poses to the lives of the citizens, remains serious for its attacks seriously impair the enjoyment of human rights (The Euro-Med Intercultural Trend 2010 THE ANNA LINDH REPORT ). They have exerted considerable effort in combating terrorism. The policy is to prevent terrorists from accessing money and weapons and bring them to justice. International co-operation is needed to strengthen through undivided commitment, this almost impossible implementing these general policies. 
- Implement in full all Security Council resolutions addressing the issue of terrorism, ensuring respect for the Charter of the United Nations, international law and international humanitarian law.

- Strive to achieve the ratification and implementation of all $13 \mathrm{UN}$ Counter-Terrorism Conventions.

- Welcome the work on the development of the UNSG's strategy to combat terrorism fully cooperating with the UN anti terrorism bodies.

- Encourage the full implementation of the standards established by the Financial Action Task Force.

- Exchange information, on a voluntary basis, about terrorists and their support networks, in accordance with international and national law.

- Work bilaterally and in accordance with national legislation to develop effective and operational cooperation to disrupt networks and bring individuals involved in terrorist acts to justice.

- Refuse asylum to terrorists and deny them safe haven in accordance with international law.

- Share expertise and best practices on countering terrorism on a voluntary basis, including technical assistance.

- Ensure respect for human rights in the fight against terrorism in accordance with international law.

- Consider convening a high level conference under the auspices of the UN to formulate an international response to terrorism in all forms and manifestations. The promoters of terrorism, regardless of means and justifications, always refer to religious and cultural causes to exonerate their actions. The world, presently, is affected by three distinct types of cultures: one that calls for peace and democratic governance, the other promotes and glorifies violence and death, while the third feeds upon apathy, indifference, and fear.

All these proposed measures can be classified as "reactive" and inefficient. Combating terrorism requires going in depth into the roots of its causes namely the religious- cultural ones.

\section{Cross-cultural Management}

The globalization of the economy, with increased ventures and global relocations, brought about major changes in the field of international customers relations and intercultural diversity management. This, in turn, led to an increased recognition by companies, that properly managing cultural differences can be a key factor in effectively reaching success across borders. It is an emerging but increasingly vital area of investigation at all human levels. It is of particular interest to global managers who work for multinational corporations. 
Cross-cultural management concerns itself with the management of diverse workforce functioning in culturally different operating environments. It is all about culture, for humans behave based on different cultural background such as: (Religion, customs, language and so forth). (Anna Lindh Review 2005-2011)

In order to take a closer look at the actual benefit of business cultural coaching, this study does first illustrate the necessary requirements for intercultural management when referring to the skills that need to be developed. This includes a detailed consideration of the possible and actual influence on international cooperation as well as the challenges faced by international working expatriates. Though intercultural management is concerned with profitability, it recognizes the importance of soft skills in implementing its percepts. Intercultural management forms a learning part in the area of organizational behavior. It seeks to ensure that all aspects of its functioning are aligned with each other. Hence, it may be recommended that global organizations do retain specialists in the field of intercultural management to anticipate and address problems. Failure to do so would allow counterproductive forces to intercultural management gain ground and even institutionalize. Furthermore, individual skills have to be properly aligned with organizational systems. There can be more than one configuration of organizational systems to promote cross-cultural management, for cultural differences can surface between managers who are presumed to have been nurtured in similar cultural influences. ."(Delhi Business Review Vol. 2, No. 2, July - December 2001)

The Anna Lindh Report is a pioneering study for knowledge and action on cross-cultural relations in the Mediterranean region. The themes discussed in the Anna Lindh Report 2010 are at the heart of public international debate, as they include: differences and Similarities in Value Systems; the Religious Factor in Intercultural Relations; Media Treatment of Cultural Diversity; Human Mobility; the role of Culture in Mediterranean Relations; Intercultural Citizenship; Islam, the West and Modernity; and the Union for the Mediterranean and Regional Cooperation. Through combining the voice of the Region and people, analyzed by experts in over 20 countries, the Anna Lindh Report has become an instrument in the hands of policymakers, opinion-leaders and civil society elite groups calling for proposals in the intercultural dialogue agenda and guidelines for intercultural action at the local and international level. It is the very first time such a EuroMediterranean Survey has been carried out on intercultural trends and values. People living in societies in Europe and in the Southern and Eastern Mediterranean region are suffering from a distorted and stereotyped perception of each other, according to a groundbreaking report on the challenges to human and cultural relations in the Region. 
Europeans misjudged the values of people in the southern and eastern Mediterranean countries, underestimating in particular the importance of religious beliefs, for people of the southern and eastern shore of the Mediterranean; respondents from southern and eastern Mediterranean countries had rather put religious beliefs as a top priority (62\%). Europeans also underrated the importance of curiosity ( $7 \%$ versus 19\%), of independence (14\% versus $20 \%$ ), and of obedience (28\% versus $35 \%$ ) in the upbringing of children in the southern and eastern Mediterranean. The main identified bridging value centered on family solidarity.

The importance of supporting intercultural exchange and transnational approaches is considered essential for the development of cultural openness within the urban setting. Facilitating exchanges between local and regional bodies of different countries focused on the development of guidelines for a culture of pluralism, respect and exchange between individuals and communities. It also aimed at ensuring the quality, more than the quantity of intercultural exchange, and investing more in innovative tools to improve the intercultural skills of people. The Report sets out a number of existing programs and tool-kits that can be maximized under different studies. The importance of these intercultural skills should be conveyed to the large majority of inhabitants of the Region, through the organizations' intercultural dialogue to help raise awareness.

The Anna Lindh Foundation brings people together from across the Mediterranean to promote and improve mutual respect between cultures in support of civil society, working for a better common future for the Region. Since its birth in 2005, the Anna Lindh Foundation launched and supported action across fields impacting on mutual perceptions among people of different cultures and beliefs. It also helped develop a region-wide Network of more than 3000 civil society organizations. (ANNA LINDH REPORT 2010)

The main scope of the Foundation's work is to overcome the misunderstandings and stereotypes that affect relations between and within societies of the Euro-Mediterranean Region.

To better understand the challenges of the human and cultural relations, the Anna Lindh Foundation also monitors and analyses the intercultural trends and values of religion as they impact human behavior and determine human activities.

\section{Social background}

Issues related to race and race relations, ethnicity and ethnic minorities, nations and national minorities, cultural pluralism, identity and difference, class and sex are major sociological topic for the partnership. 
(Will Kymlicka, Multicultural Citizenship: A Liberal Theory of Minority Right)

Culture refers to characteristic patterns of beliefs, values,attitudes, and behaviors shared by a population they include language, customs, beliefs, traditions and ways of communicating; which differ from one country to another in the Euro Med zone.

It is a way of thinking, living, and behaving, learned within the family including defined ways to resolve problems. Ethnicity in contrast is closely related to culture, although ethnicity usually refers to a particular cultural group or race that interacts and share common interests. Often there is as much diversity within ethnic groups as between them. (Mc Laughlin, L., \& Braun, K. 1998). ("Asian and Pacific Islander cultural values: Considerations for health care decision-making.” Health and Social Work)

Minority is defined as a group outnumbered by persons who do not belong to it. This can be used to refer to people of a different culture, language, nationality, religion, lifestyle or any similar characteristic. (Council of Europe,Training Resources: Education for democratic citizenship, "Learning tolerance”, ANNEXES, Silvia Jindra, Robert Etlinger\& Silvia Wiesinger - Austria, Edited by Pascale Mompoint Gaillard, November 2007)

The wealth of the Euro-Med area is the coexistence of a high percentage of minorities that make it unique. Due to different social, cultural and political factors, some minorities are being extinct while others struggle to survive.(Euromed youth educational report, Role and Place of minorities in the Euromed context: ethnic, linguistic and religious, (Salto-Youth, Euro Med resource center, Caroline Mayaudon, November 19, 2009)

\section{Religion}

Persons belonging to religious minorities often have a faith different from that held by a majority. Nowadays the essence of human rights principle is the freedom to choose one's own religion and beliefs, including the right to convert from one religion to another. However in some member countries this freedom is clearly restricted by heavy penalties including death.( Euromed youth educational report, Role and Place of minorities in the Euromed context: ethnic, linguistic and religious, Salto-Youth, Euro Med resource center, Caroline Mayaudon, November 19, 2009)

\section{Gender}

While in most societies, men and women enjoy equal rights, the status of women in the Arab-Med partnership is subjected to aggression, discrimination and violence. 
Age

The elderly, while traditionally dominant or influential in the past, have been reduced to a minority role of economically "non-active" groups. Children can also be considered under the term called adultism.

Elderly people in contrast to European countries have no social security plans that care for them. Furthermore, The sexual minorities of LGBT have different statuses in individual member countries.( Euromed youth educational report, Role and Place of minorities in the Euromed context: ethnic, linguistic and religious, Salto-Youth, Euro Med resource center, Caroline Mayaudon, November 19, 2009)

\section{Obstacles Facing Exchange of Cultures in Euro-Med:}

The Euro-Med zone embraces many cultural differences due to the wide diversification in its membership. This is caused by the lifestyle of the people in those geographical areas, their history, their art, architecture, religions, and other elements that help shape their way of life.

Consequently, the road towards a Euro-Mediterranean cultural partnership faces a huge credibility problem, in the absence of a common regional goal. The most important factor is confronting violence because there are always wars in different Mediterranean countries like Syria, Egypt, Tunisia and Palestine... This hinders the exchange of cultures because in a war situation there is a mess and no one respects other cultures. People have also other priorities, mainly economic and religious differences, which make it impossible sometimes to share cultures.(Lorenzo KihlgrenGrandi)

The purpose of the Anna Lindh Foundation (ALF) is to bring people together from across the Mediterranean, to improve mutual respect between cultures and to support civil societies working for a common future of the Region. The Foundation's program focused on activities in fields such as: Education and Youth; Culture and Arts; Peace and Co-existence; Values, Religion and Spirituality; Cities and Migration; Media. The ALF aims to contribute to the development of an Intercultural Strategy for the EuroMediterranean Region, providing recommendations to decision-makers and institutions and advocating sharing values. (André Azoulay, President of the Anna Lindh Foundation)

The results so far indicate that there are many initiatives to approach Euro-Med countries; unfortunately, not successful because most European countries respect freedom namely, the right of speech and all human rights, not only by law but by practice. In contrast some Mediterranean countries are suffering from violence and war, braking up the process of exchanging cultures. (Barcelona summit 1995) 


\section{Globalization and cultural diversity.}

Globalization is the process by which relatively separated zones come to intersect in the same "imaginary” space (Doreen Massey-Pat Jess, 2001). Globalization, as suggested by Ian Clark (in Zolo, 2005), influences alterations linked to spatial and international relations dimensions, it includes concepts of integration, interdependence, multilateralism, openness, spatial compression and homogeneity

This necessitates mastering of two types of communication: local and global, both aiming at promoting the understanding of each partner's priorities. Nevertheless the Euro-Med region is strategically important in determining and sustaining global socio-economic trends.

Most important are issues of diversity in management mechanisms, violations of minority rights, gender equity, and civil society empowerment.

Undeniably, the variety of established programs, forums and institutions to tackle these ills offer an existing opportunity that should be further developed and empowered to act as an effective multilateral forum not only for dialogue but also for action. (Assem Reda Abu Hatab, 2009)

\section{Challenges to tackle}

1. The heated cultural and religious aggression dominated the international system after September 11, causing the US to lead the world to combat terrorism. This was constructed by many to be a confrontation with Islam; consequently, it influenced intercultural dialogue between the EU and south Mediterranean Muslim countries, even though the EU adopted an open approach to exchange ideas among cultures. Indeed, the rise in Islamic fundamentalism embodied in the multiplicity of terrorist Islamic organizations, contributed to slowing down the pace of intercultural dialogue between the two shores of the Mediterranean. It became further unavoidable to all actors in the Mediterranean to take into account the growing hegemonic presence of the United States in the region, backing down EU actions and working to marginalize intercultural dialogue in the EMP itself. Furthermore, despite the clear civilized approach adopted by the EU, it has inevitably embraced ample restrictions on the mobility of, and exchange programs for groups and individuals in particular students, scholars, researchers, artists, and journalists in the Mediterranean region. This has been noticeably manifested in the regulations stipulated by the EU under the Area of Freedom, Security and Justice (AFSJ), which was introduced into the EU Treaty framework by the Treaty of Amsterdam in 1997. It incorporates migration laws, family gathering law, refugee's laws, police cooperation, and cooperation 
in criminal laws, the AFSI took on measures to organize aspects of immigration and borders control in addition to the development of security and anti-terrorism procedures, which are of major tension in its social and cultural relations with its Arab partners. Considering the sizable Arab Muslim community in the European continent and the initiated social and cultural venues of cooperation between the EU and these Arab countries, the adopted measures to control immigration and restrict mobility of peoples from the south into the EU were perceived as serious barriers to an effective intercultural dialogue.

These measures contributed to widening instead of bridging the gap between the two shores of the Mediterranean, because the EU appears to be torn between two contradicting "measures" that serve its security; the first is intercultural dialogue for confidence building, while the second stipulates and puts into effect a wide range of anti-terrorism regulations that unavoidably hamper an effective intercultural dialogue and greatly diminish the EU credibility in that dialogue.

2. There is lack of a common strategic language especially when handling cultural differences. Although, there is a consensus in the region on what could be referred to as "universal values", as well as a clear identification of the problems to handle in an intercultural dialogue, still there is a divergence in European and Arab perceptions on how to approach cultural differences in a common language.

3. The underfunding of activities listed under the third social and cultural basket of the EMP compared to other political and economic baskets greatly undermines the authenticity of an effective intercultural dialogue and priorities. (Kramsch, 1998)

Intercultural communication is a central process in the EuroMediterranean dialogue. This study seeks to broaden understanding of cultural differences. To achieve this objective managers and leaders should become knowledgeable of the communicative ability model between both cultures. In conclusion, it is important to remember that the effect of culture upon society and people is impossible to quantify. (Balboni 2007)

\section{Women's Rights in the Euro-Mediterranean partnership}

When mentioning women's rights in the Euro-Mediterranean region, one must divide those rights into two categories: the public rights, and the private ones, particularly within the family context. There is the need to stress that civil and political, social and economic rights of women are indivisible and interdependent. These four categories belong to the "public" 
sphere. Women have important roles in the family domain having its own system of religious, civil laws and norms.

The United Nations unanimously adopted the UN Development Declaration setting long-term goals for the year 2015 in an attempt to enhance women growing prospects through reforms in the institutional frameworks granting women's full participation in the local economies.

Accordingly, the Euro-Med Partnership stresses the need for a twodimensional treatment of the rights of women in the EMP partner states. The rights of women should constitute an integral part of the general human rights and be evaluated on the basis of equality and non-discrimination, including the rights to maternity. Women are equal to men; although different.

Unfortunately, The Work Program has no "road map" or timetable about when and to what extent partner governments should implement these goals. Furthermore, the Work Program is not politically binding, since based on past experience, this is unlikely to induce much change. In this context, the ministerial future meeting should address the issue of how to ensure, that clear objectives are stated along with clear benchmarks for application with evaluation mechanisms.

Progress on promoting women's rights initiatives within the EMP has been relatively slow and marred with challenges. Women, and especially those from the MENA region, were absent from the establishment of the Partnership. Reference to women's rights in the Barcelona Declaration is only stated in relation to European women's role in economic development, with no specific mention of women's rights in the Association Agreements.

\section{Violation of Women Rights}

It is ironic that each member of the MENA countries has signed the Convention on the Elimination of All Forms of Discrimination against Women. It was only done so far on paper as many reservations were added to contravene the spirit and letter of the Convention. Governments in the region must invest all necessary efforts to ensure that the systematic discrimination and violence against women is permanently halted.

\section{Conclusion}

This paper attempted to identify the differences between developed and developing partners in the Mediterranean basin. Countries like Germany, Italy and France are ahead by about 100 years from other mainly Arab Mediterranean countries. Revolutions, happening now in Arab world, occurred hundreds of years ago in Europe with the similar symbols: "no more kings, liberty or death" freedom, human rights were all shouted in France, Italy, and others as humanity evolved toward tolerance and equality. 
Global changes have been racing with discoveries, time and technologies. People and societies are moving closer through the media. Unfortunately, based on numbers and statistics the Arab countries rank lowest, socially, politically and even economically, consequently, the EuroMed partnership opens new space and horizons for advancement and cultural evolution promoting international cooperation, and mostly peace.

\section{References:}

Chammari, K. (2007). Euro-Mediterranean human rights network. Retrieved from

http://www.ohchr.org/Documents/Issues/FAssociation/Responses2012/other _contributions/World-

EMHRN2007_Annual_Report_on_Free_Association.pdf

Ghantous, M. (2007). Euro-Mediterranean human rights network. Retrieved from

http://www.ohchr.org/Documents/Issues/FAssociation/Responses2012/other _contributions/World-

EMHRN2007_Annual_Report_on_Free_Association.pdf

Guillet, T. (2007). Euro-Mediterranean human rights network. Retrieved from

http://www.ohchr.org/Documents/Issues/FAssociation/Responses2012/other contributions/World-

EMHRN2007_Annual_Report_on_Free_Association.pdf

El Yazimi, D. (2012). In Isa Gry Lindemann Elowsson (Chair). The current key challenges of the human rights movement. Presentation delivered at the seminar Euromed seminar: challenges faced by the human rights movement, Copenhagen. Retrieved from http://euromedrights.org/eng/wpcontent/uploads/2012/09/Seminar-report_EN.pdf

Integration of women's rights into the Euro-Mediterranean partnership rabea naciri/isis nusair May 2003

Fédération internationale des ligues des droits de l'Homme (FIDH): Algérie, les violence contre les femmes: L'état des lieux en 2001. Report addressed to the Special Rapporteur of the Commission on Human Rights on violence against women.

Human Rights Watch: World Report, 2000.

Human Rights Watch: World Report, 2001.

Abu-Nimer, M.,Khoury A. and Welty, E. (2007). Unity in diversity: interfaith dialogue in the Middle East, Washington, D.C. :United States Institute of Peace Press.

Accame, S. (1966). La Formazione della civiltá mediterranea. Brescia: La Scuola. 
Al-Azmeh, A. and Fokas, E. (Eds.) (2007). Islam in Europe: Diversity, identity and influence. Cambridge: Cambridge University Press.

Albera, D. and Tozy, M. (eds.) (2005) La Méditerranée des Anthropologues. Paris: Maisonneuve et Larose.

Albera, D. and Tozy, M. (Eds.) (2005). La Méditerranée des Anthropologues. Paris: Maisonneuve et Larose.

Arbel, B. and Jacoby D. (1996). Intercultural Contacts in the Medieval Mediterranean. Portland and London: Frank Cass.

Argyle, M. (1972). The Psychology of Interpersonal Behaviour. Harmondsworth: Penguin.

Bailyn, B. (1951). 'Braudel’s Global Geohistory - A reconsideration'. Journal of Economic History, 11. pp. 277-282.

Banchoff, T. (Ed.) (2007). Democracy and the new religious pluralism. New York: Oxford University Press.

Bargh, J.A. and McKenna, K.Y.A. (2004). 'The Internet and Social Life', Annual Review of Psychology, vol. 55, pp. 573-90.

Bird A (ed.) (2002) Encyclopedia of Japanese Business and Management,

London: Routledge.

Briscoe D and R Schuler (2004) International Human Resource Management,

London: Routledge.

Chartered Institute for Personnel and Development, website:

www.cipd.org.uk

Chen M (2004) Asian Management Systems, London: Thomson.

Ford D, L-E Gadde, H Håkansson and I Snehota (2003) Managing Business Relationships, Chichester: Wiley.

Giddens A (1989) Sociology, Cambridge: Polity.

Handy CB (1003) Understanding Organizations: London: Penguin.

Harris H, C Brewster and P Sparrow (2003) International Human Resource Management, London: CIPD.

http://ec.europa.eu/enterprise/policies/international/promoting-

neighbourhood/mediterranean/

http://ec.europa.eu/enterprise/policies/international/files/work-programme-

2011-2012_en.pdf

http://ec.europa.eu/enterprise/policies/international/files/short-report-

2012_en.pdf

http://ec.europa.eu/europeaid/where/neighbourhood/regional-

cooperation/irc/investment_en.htm

http://eeas.europa.eu/euromed/barcelona_en.htm

http://europa.eu/legislation_summaries/external_relations/relations_with_thir

d_countries/mediterranean_partner_countries/rx0001_en.htm

www.euromedbarcelona.org/EN/PtoEncuentro/ACptoEncuentro/index.html 
www.barcelona.com/barcelona_news/the_barcelona_process_or_euro_medit erranean_partnership http://ec.europa.eu/external_relations/euromed/ www.europarl.europa.eu/intcoop/empa/default.htm www.consilium.europa.eu/ueDocs/cms_Data/docs/pressData/en/ec/99410.pd $\mathrm{f}$

www.eeas.europa.eu/euromed/index_en.htm www.euromedheritage.net/ www.euromedp.org/ www.enpi-info.eu/files/publications/AnnaLindhReport2010.pdf http://eeas.europa.eu/lebanon/csp/nip_05_06_en.pdf http://en.wikipedia.org/wiki/Euro-Mediterranean_Partnership http://idec.gr/iier/new/EN/Steinbichler\%20Paper\%20GR.pdf http://ec.europa.eu/europeaid/where/neighbourhood/regionalcooperation/documents/infonotes_enpisouth_regional_cooperation_en.pdf http://en.wikipedia.org/wiki/Union_for_the_Mediterranean www.euromedheritage.net/euroshared/doc/press\%20release\%20\%20conference\%20-eh4\%20-\%20final\%20en.pdf www.enpi-info.eu/mainmed.php?id_type $=1 \& i d=30966 \& l a n g \_i d=450$ www.novasol.co.uk/holiday-cottages/croatia/culture.html www.touregypt.net/epeople.htm NE8108229ENC_002.pdf from Bookshop.europa.eu www.placesonline.com/ www.turkishodyssey.com/turkey/culture/people.htm www.cia.gov www.web.worldbank.org www.mongabay.com www.invest.gov www.indexmundi.com www.infoplease.com www.enpiinfo.eu/medportal/content/340/About\%20the\%20EuroMed\%20Partnership www.tandfonline.com/doi/abs/10.1080/13629399608414564\#.UYPke3rfrV9 www.tandfonline.com/doi/abs/10.1080/03932729708456774\#preview www.cepii.fr/\%5C/anglaisgraph/workpap/pdf/2011/wp2011-07.pdf El MahdiAlia, El Khawaga Ola,and El Araby Ashraf, Education and Social Protection Systems in Southern and Eastern Mediterranean Countries.MEDPRO Technical Report No. 20/January 2013 www.euromedalex.org/ www.euromedbarcelona.org/EN/PtoEncuentro/ACptoEncuentro/index.html http://ufmsecretariat.org/business-development/ http://ufmsecretariat.org/mediterranean-initiative-for-jobs-med4jobs/ 
http://ufmsecretariat.org/euro-mediterranean-development-centre-for-microsmall-and-medium-enterprises/

http://ec.europa.eu/comm/external_relations/euromed/free_trade_area.htm) www.emuni.si/press/ISSN/1855-3362/2_121-139.pdf

www.emuni.si/press/ISSN/1855-3362/2_121-139.pdf 